L. V. Dotsenko, V. I. Chorna, Yu. I. Hrytsan, N. V. Voroshylova $\square$, V. V. Katsevych

Dnipro State Agrarian and Economic University, S. Yefremov Street, 25, Dnipro city, Ukraine, 49600

\title{
BIOENVIRONMENTAL CHARACTERISTICS OF ROBINIA PSEUDOACACIA STEPPE PLANTATIONS IN DEPENDENCE TO CHANGES IN SOME CLIMATIC FACTORS
}

Climatic factors play the most important role in the plant associations formation. Sunlight is one of the leading factors that determine the appearance of a particular community and very often plays the limiting factor role. In the conditions of the Steppe Dnipro Region, its limiting role can be expressed only in its excess. The great majority of autochthonous steppe flora plant species has strongly pronounced adaptations to excessive solar insolation. With the development of forest biogeocenology and steppe forestry, more and more attention is paid to the issues of forest climatology. It is shown that climatic factors have an imperative effect on the formation of soils, plant associations, fauna and ecosystems in general. Artificial plantations consisting of fast-growing hardwoods, such as Robinia pseudoacacia, have been studied. The complex of abiotic factors in robinia plantations and in open areas has its own characteristics. The processes of reflection, transformation and accumulation of solar energy in tree plantations have a slightly different character than in forest-free areas. In the Dnipropetrovsk region, the populations of Robinia pseudoacacia are represented mainly by young plants that have already entered the phase of active fruiting. No plants older than 100 years were found in the populations. Thus, the price spectrum of the age composition of the population of Robinia pseudoacacia in the Dnipropetrovsk region has a pronounced left-sided character, ie shifted towards young individuals that are actively fruiting. This indicates that the processes of expansion of Robinia pseudoacacia to natural biogeocenoses will be actively continued. Despite the fact that this breed has a number of positive qualities (excellent medonis, root mycorrhiza with azotobacter, high gas resistance, etc.), the processes of uncontrolled active settlement of this species is a matter of serious concern. This breed is capable of rapid spread and disruption of successional processes occurring in the area. In the conditions of the forecasted climate changes towards temperature increase and precipitation decrease this breed receives more and more advantages.

Ключові слова: climatic factors, plant associations, robinia pseudoacacia, insolation.

\section{Л. В. Доценко, В. І. Чорна, Ю. І. Грицан, Н. В. Ворошилова $\square$, В. В. Кацевич}

Дніпровський державний аграрно-економічний університет, Дніпро, Украӥна

\section{БІОЕКОЛОГІЧНА ХАРАКТЕРИСТИКА СТЕПОВИХ НАСАДЖЕНЬ РОБІНІЇ ПСЕВДОАКАЦІЇ В ЗАЛЕЖНОСТІ ВІД ЗМІН ДЕЯКИХ КЛІМАТИЧНИХ ЧИННИКІВ}

Кліматичні фактори відіграють провідну роль у формуванні рослинних асоціацій. Сонячне світло є одним із головних факторів, що визначають вигляд

Tel.: +38050-932-91-19. E-mail: khlyzina@ukr.net

DOI: $10.15421 / 442101$ 
того чи іншого угруповання і дуже часто відіграє роль лімітуючого фактора. В умовах степового Придніпров'я його обмежувальна роль може бути виражена тільки в його надлишку. Переважна більшість видів рослин степової автохтонної флори має яскраво виражені пристосування до надлишкової сонячної інсоляції. Зі становленням лісової біогеоценології та степового лісознавства все більше уваги приділяється питанням лісової кліматології. Показано, що кліматичні фактори мають імперативний вплив на формування грунтів, рослинних угруповань, тваринний світ та й у цілому на екосистеми. Були досліджені штучні лісонасадження, що складаються зі стійких порід, які швидко зростають, як, наприклад, робінія псевдоакація. Комплекс абіотичних факторів у насадженнях робінії і на відкритих ділянках має свої характерні особливості. Процеси відбиття, перетворення та акумуляції сонячної енергії в деревних насадженнях мають дещо інший характер, ніж на безлісній місцевості. На території Дніпропетровської області популяції робінії псевдоакації представлені в основному молодими рослинами, які вже вступили у фазу активного плодоношення. Рослин, що старші за 100 років, у популяціях не виявлено. Таким чином, ценоспектр вікового складу популяції робінії псевдоакації на території Дніпропетровської області має яскраво виражений лівосторонній характер, тобто зміщений у бік молодих особин, які активно плодоносять. Це вказує на те, що процеси експансії робінії псевдоакації на природні біогеоценози будуть активно продовжуватися. Незважаючи на те що ця порода має цілий ряд позитивних якостей (відмінний медоніс, коренева мікориза 3 азотобактером, висока газостійкість та ін.), процеси неконтрольованого активного розселення цього виду викликає серйозне занепокоєння. Ця порода здатна до швидкого розповсюдження і порушення сукцесійних процесів, що відбуваються в даній місцевості. В умовах прогнозованих змін клімату в бік підвищення температури і зниження кількості опадів ця порода отримує все більше переваг. інсоляція

Key words: кліматичні фактори, рослинні асоціації, робінія псевдоакація,

\section{Introduction}

It is a matter of common knowledge that climatic factors play the most important role in the plant associations formation. Sunlight is one of the leading factors that determine the appearance of a particular community and very often plays the limiting factor role. In the conditions of the Steppe Dnipro Region, its limiting role can be expressed only in its excess. The great majority of autochthonous steppe flora plant species has strongly pronounced adaptations to excessive solar insolation.

The forest timber species in steppe conditions is affected by a number of negative limiting factors, which include cereals heavy sod, which, with their fibrous root system, receive a significant part of the incoming moisture in the upper horizons and make it extremely difficult for the natural renewal of tree species, whose seedlings have a poorly developed taproot system and are not very competitive under these conditions. The forest timber species, especially in the early stages of germination, very poorly tolerates fires, which often occur in these conditions, in contrast to cereals, which receive good protection from peat felt.

The interaction features of the forest biogeocenosis with the habitat, in particular climatic factors, are comprehensively disclosed in the works of H. M. Vysotskyi, who is 
the author of the "doctrine of forest pertinence", where he reveals in detail the aspects of the environment-transforming action (pertinence) of forest vegetation $[53,54,55,56]$.

Later, many scientists developed these views, in particular in the works of M. V. Dylis, where climatope is identified with the atmosphere specific state and properties, the material and energy resources of which are included in all links of the biogeocenotic process $[12,13]$.

With the development of forest biogeocenology and steppe forestry, more and more attention is paid to the issues of forest climatology. It is shown that climatic factors have an imperative effect on the formation of soils, plant associations, fauna and ecosystems in general $[4,5,10,11,15,16,37,41,42,49]$.

At the moment, most of the works of scientists are devoted to the impact of climate change, adaptation processes of organisms to these changes and forecasting possible both regional and large-scale long-term environmental consequences in Ukraine and abroad (Sedjo, 1998).[55, 13, 18, 32-36, 50, 51].Climate changes and ecological consequences for forest ecosystems, climatic variability and evolution of their landscapes, the influence of the greenhouse effect (Ukraine and the global greenhouse effect $[38,40]$, etc.) have been investigated and analyzed.

It is shown that the radiation regime under the forest canopy largely depends on its individual characteristics - the composition and age of the stocking, the canopy closure, its openness, the presence of the vegetation lower layers, completeness, yield class, etc. The properties and amount of radiant energy entering under the crowns of trees is due to the phenological composition of tree species and depends on the height of the stocking, and is also influenced by the wind $[1,2,7,8,35,36,45-48,50,51]$.

A. H. Mirosh [43, 44], Z. H. Ustsova [52], Yu. I. Hrytsan [19], I. A. Ivanko [32-34] in their works pay special attention to the light regime of artificial afforestation of the steppe zone of Ukraine.

Excessive solar insolation also makes its negative contribution to the formation of a natural stocking in the steppe. Forest vegetation in the south-east of Ukraine, with the exception of floodplains and wooded ravines, is azonal and is forced to experience strong competition with zonal steppe vegetation. The original tree flora of this region, traditionally confined to the floodplains and cleavages, was represented mainly by dense-crowned species (English oak, wych elm, horse chestnut, Norway maple, lindens, black poplar, bird cherry, etc.).

The concept of sustainable development of agroecosystems for the period up to 2025, approved by the Presidium of the National Academy of Agrarian Sciences of Ukraine in 2003, provides for the intensification of work both to preserve forest gene pools and to purposefully increase the area of forest plantations [14].

The bulk of artificial forest plantations created under these conditions is represented by windbreakers. In most cases, these plantations were created by stable, fast-growing species, often not inherent in the flora of this region, such as, for example, Robinia pseudoacacia.

The complex of abiotic factors in Robinia plantations and in open spaces has its own characteristic features. The processes of reflection, conversion and accumulation of solar energy in tree plantations have a slightly different character than in unforested areas.

\section{Results and discussion}

In order to study the development peculiarities of artificial plantations of robinia and its effect on the illumination of the grass cover, three test plots were selected, with a predominance of 60-, 15- and 5-year-old trees in the age structure, the first of which 
forms forest strips of wood near farmland near the Maiorka village of Dniprovskyi district of Dnipropetrovsk region.The 60-year-old plantation is an artificially created strip of wood, and the 15-year-old and 5-year-old plantations are the result of natural regeneration of the Robinia plantation. Since the original 60-year-old plantation was created artificially, it is significantly crowded compared to the other two plots that arose by natural seeding. The control point was a site devoid of forest timber species.

Illumination measurements under the canopy were carried out by seasons (winter, spring, summer, autumn) using the Flus ET-965 multifunctional device at 12.00.

According to I. A. Ivanko [32] the average illumination under radiation type of weather in forest cultures, biogeocenoses of the illuminated type of light structure relative to open areas is $14.2 \%$, semi-illuminated $-8.4 \%$, half-shade $-5.4 \%$, shadow $2.4 \%$. In general, a similar tendency was observed in the studied plantations. Robinia pseudoacacia is a typical open-cropped breed that can create only slight shading under its canopy. In the 60-year-old plantation, the average illumination was $45.8 \%$ compared to the open unforested area and naturally increased with decreasing age and plant density, respectively, up to $59.2 \%$ in 15 -year-old plantations and up to $76.4 \%$ in 5 -year plantations.

Abiotic factors in Robinia plantations are in close physical relationship with the forest itself and are influenced by it. This influence extends to the adjacent territory, subjecting the course of natural processes to its direction. In such a situation, the course of the natural autotrophic allogenic succession, which is the restoration of steppe vegetation, is largely disturbed and can lead not to the formation of a climax steppe biogeocenosis, but to the formation of a savanna-type association in which the typical steppe flora of southeastern Ukraine will be interspersed with freestanding robinia pseudoacacia trees.

Such changes in the flora, in their turn, will lead to changes in the faunal complex. For example, Robinia pseudoacacia bears abundant fruit with rather large seeds, which are readily eaten by murine rodents. Agricultural lands adjacent to plantations are also actively populated by these animals. These factors will contribute to a sharp increase in the number of murine rodents, which are not only pests, but also carriers of many dangerous diseases. At the same time, there will be no factors of natural restraint of their number in the form of an increase in the number of predators. Rare clear-boled plantations of Robinia pseudoacacia, like adjacent agrocenoses, do not provide predators with the necessary shelters, which is why they are extremely reluctant to settle there.

In this regard, the current trend in afforestation on the territory of the region causes concern, when plantations are created in natural areas not from the most widespread, stable and recreationally valuable species (common oak, Norway maple, heart-shaped linden, etc.), but mainly from white acacia, which tends to expand into natural steppe and meadow areas, which reduces the value of landscapes for recreation and green tourism.

As of 01.01.2020, on the territory of the Dnipropetrovsk region, wooded land is 77.0 thousand hectares. Among them, plantations of Robinia pseudoacacia in pure or mixed breeds account for 17683.7 hectares or $22.9 \%$ of the forested area.

Figure 1 shows the areas that are occupied on the territory of the Dnipropetrovsk region by plantations, consisting mainly of Robinia pseudoacacia, as well as areas under mixed plantings with its participation. 


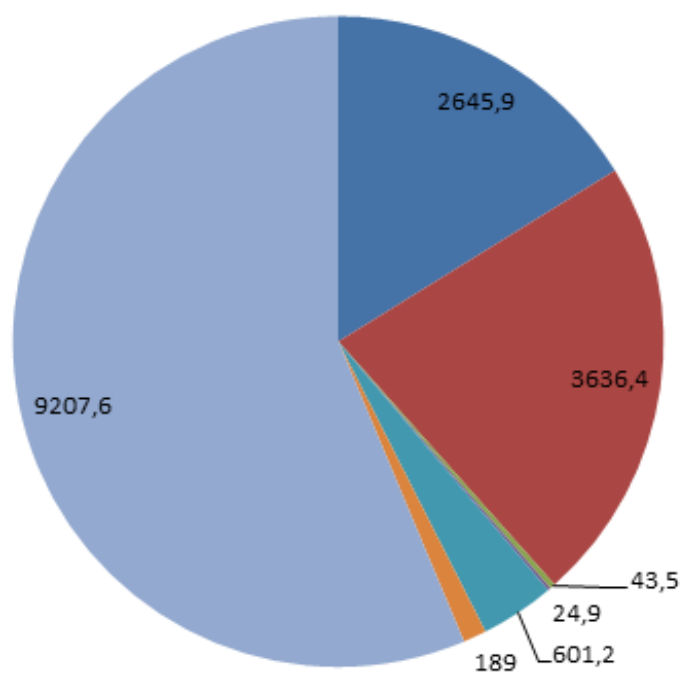

- Acer campestre sudibrova, he

Ulmus minor- Acer campestre dibrova, he

Pinus bor, he

- Ulmus minor, sudibrova, he

- Subor, he

- Steppe sudibrova, he

Robinia pseudoacacia, he

Fig. 1. Participation of Robinia pseudoacacia in the structure of tree plantations in Dnipropetrovsk region.

Robinia pseudoacacia is a long-lived breed of up to 300 years. At the same time, fruiting occurs at 6-7 years. Therefore, from the point of view of predicting the distribution of this species, the age structure of the population plays a very important role. On the territory of the Dnipropetrovsk region, the population of Robinia pseudoacacia is represented mainly by young plants that have already entered the phase of active fruiting. Plants over 100 years old were not observed in the population (Fig. 2).

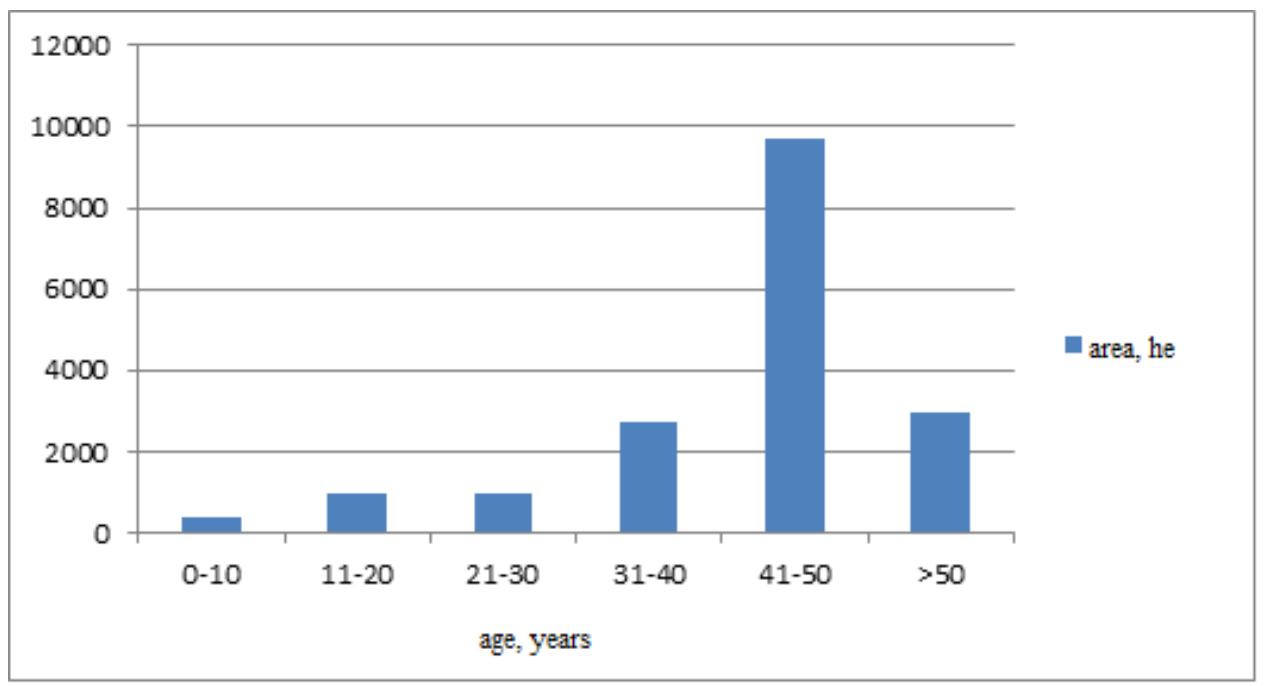

Fig. 2. Distribution of areas under plantations of Robinia pseudoacacia of different ages on the territory of the Dnipropetrovsk region 


\section{Conclusions}

Consequently, the spectrum of the age state of the Robinia pseudoacacia population on the territory of the Dnipropetrovsk region has a pronounced left-sided character, that is, it is biased towards young and actively bearing individuals. This indicates the further active continuation of the Robinia pseudoacacia expansion on natural biogeocenoses. And despite the fact that this breed also has a number of positive qualities (excellent nectar-bearing plant, root mycorrhiza with azotobacter, high gas resistance, etc.), the processes of uncontrolled active settlement of this species cause serious concerns.

At the moment, almost a quarter of the forested areas of the Dnipropetrovsk region are under plantings of Robinia pseudoacacia in pure form or mixed to varying degrees with other tree species. This situation poses a real threat to both natural steppe areas and the original tree flora of the region. Robinia pseudoacacia is a long-lived species resistant to a lack of moisture and excessive solar insolation, undemanding to soils, practically free of pests in the conditions of the Dnipropetrovsk region, that is, it is a typical eurybiontic species. This tree species is capable of spreading quickly and disrupting the natural succession processes that occur in a given area. Under the conditions of the predicted climate change in the direction of increasing temperature and decreasing precipitation, this breed acquires even more advantages. Therefore, in order to prevent the Robinia pseudoacacia uncontrolled spread, it is necessary to develop a set of measures that should be carried out on the territory of the Dnipropetrovsk region in the near future.

\section{Bibliographic references}

1. Aleksieiev V. A. Some issues of the optical properties of the forest. Problems of ecology and physiology of forest plants. Leningrad, 1963. P. 47-78.

2. Aleksieiev $\boldsymbol{V}$. A. On the transmission of solar radiation by the canopy of the stocking. Light regime, photosynthesis and forest productivity: collection of scientific papers. Moscow, 1967. P. 15-35.

3. Bahuguna R.N., Jagadish K.S.V. Temperature regulation of plant phonologicaldevelopment. Environ. Exp. Bot. 2015. Vol. 111 (3). P. 83-93.

4. Beresneva I.A. Mesoclimatic resources of the arid zone of Asia: Abstract of the Dissertation of the Doctor of Geographical Sciences. St. Petersburg, 1992. 48 p.

5. Boychenko S., Voloshchuk V., Movchan Y., Serdjuchenko N., Tkachenko V., Tyshenko O. Features of Climate Change on Ukraine: Scenarios, Consequences for Nature and Agroecosystems. Proceedings of the National University. 2016. Vol. 4. P. 96-113.

6. Breda N., Huc R., Granier A., Dreyer E. Temperate forest trees and stands undersevere drought: a review of ecophysiological responses, adaptation processes andlong-term consequences. Ann. In. For. Sci. 2006. Vol. 63. P. 625-644.

7. Budyko M.I. Climate in the past and future. Leningrad: Hydrometeoizdat, 1980. $351 \mathrm{p}$.

8. Budyko M.I. Thermal balance of the earth's surface. Leningrad: Hydrometeoizdat, 1956. 256 p.

9. Didukh Ya.P. Environmental aspects of global climate change: causes, consequences, actions. Bulletin of the National Academy of Sciences of Ukraine. 2009. No. 2. P. 34-44.

10. Drozdov O.A. Droughts and moisture dynamics. Leningrad: Hydrometeoizdat, 1980. 93 p. 
11. Drozdov O.A. Basics of climatological processing of meteorological observations. Leningrad: Publishing House of the Leningrad State University, 1956. $302 \mathrm{p}$.

12. Dylis N.V. Basics of biogeocenology. Moscow: University Publishing House, 1978. $152 \mathrm{p}$.

13. Dylis N.V. The structure of the forest biogeocenosis. Moscow: Science, 1969. $56 \mathrm{p}$.

14. Furdychko I.O. Forestry of Ukraine: development prospects in the formation of sustainable agroecosystems. Agroecological journal. 2003. No. 3. P. 3-10.

15. Gates D.M. Climate and the response of forests. Int. J. Remote Sens. 1990. Vol. 11, No. 7. P. 1095-1107.

16. Hrytsan Yu.I. Microclimatic features of the conditions of existence of forest ecosystems on the right-bank of the Samara River. Monitoring studies of biogeocenotic catenas of the steppe zone. Dnipropetrovsk: Dnipropetrovsk State University, 1995. P. 34-61.

17. Hrytsan Yu.I. The ecoclimate of the ravine forests of the Samara River. Issues of steppe forestry and forest land reclamation. Dnipropetrovsk: Dnipropetrovsk State University, 1997. P. 39-49.

18. Hrytsan Yu.I. The ecological and climatic characteristics of the conditions for the growth of forest vegetation (the microclimatic aspect of dendroindication). Bulletin of the Dnipropetrovsk University. Biology and Ecology. 1996. P. 53-70.

19. Hrytsan Yu.I. Ecological bases of transforming influence of forest vegetation on steppe environment. Dnipropetrovsk, 2000.300 p.

20. Hrytsan Yu.I., Karas L.M., Dubynets N.V., Tyrsa A.R., Ruska Yu.O., Karas $\boldsymbol{O}$.H. Study of the properties of climatic forest plantations of the steppe (to the 55th anniversary of the KEDU. The issue of steppe forestry and forest land reclamation. Dnipropetrovsk: Dnipropetrovsk State University, 2004. Edition 8 (33). P. 55-66.

21. Hrytsan Yu.I., Karas O.H. Determination of climate gradations in studies of pertinent biogeocenology. Ecology. Noospherology. Kyiv - Dnipropetrovsk, 2007. Vol. 18, No. 3-4. P. 119-124.

22. Hrytsan Yu.I., Karas O.H. Ecoclimatic studies of the oxbows of the Samara coniferous forest. Biodiversity of aquatic ecosystems: issues and solutions: materials of the all-Ukrainian scientific and practical conference with international participation. Dnipropetrovsk, 2008. P. 21-23.

23. Hrytsan Yu.I., Karas O.H., Baranovskyi B.O. Peculiarities of meteorological processes in the floodplain (on the example of Samara coniferous forest). Bulletin of the Kryvyi Rih Technical University. Kryvyi Rih, 2005. Edition 10. P. 222-227.

24. Hrytsan Yu.I., Karas O.H., Zaiko N.V. Characteristics of the climatopes of a short floodplain oak forest. Bulletin of the Dnipropetrovsk University. Biology. Ecology. Dnipropetrovsk: Dnipropetrovsk State University, 2002. Edition 10, Vol. 2. P. $230-235$.

25. Hrytsan Yu.I. Anemometric characteristics of near-watershed forest biogeocenoses of the Samara River. The issues of steppe forestry and forest land reclamation. 1999. Edition 3. P. 30-37.

26. Hrytsan Yu.I. Features of vertical distribution of air temperature in ravine. Anthropogenic impact on forest ecosystems steppe zones. 1990. P. 21-24. 
27. Hrytsan Yu.I. Consideration of the environment-transforming and transgressive influence of micro-, meso- and macrobiogeocenosesystems in the design of forests in the steppe. The issues of steppe forestry and forest land reclamation. 2002. Edition 6. P. 31-41.

28. Hrytsan Yu.I. Dendroindication of microclimatic conditions. Bulletin of the Dnipropetrovsk University. Biology and ecology. Dnipropetrovsk: Dnipropetrovsk State University, 1993. Edition 1. P. 208-209.

29. Hrytsan Yu.I. Microclimate of near-watershed natural steppe biogeocenoses. Biogeocenological studies of forests of technogenic landscapes of steppe Ukraine. Dnipropetrovsk: Dnipropetrovsk State University, 1989. P. 74-83.

30. Hrytsan Yu.I., Baranovskyi B.O., Karas O.H., Ivanko I.A., Kotovych O.V., Oleksandrova A.O. Natural conditions and phyto-diversity of the Samara River floodplain in one of the largest forest areas of the steppe "Samara Forest". Ecological Bulletin. Nizhyn, 2006. No. 5. P. 7-10.

31. Ivanko I.A. Features of the influence of forest woody vegetation on the formation of the light regime of natural floodplain ecosystems of the steppe zone of Ukraine. The issues of steppe forestry and forest land reclamation.2010. Edition 14. P. 81-86.

32. Ivanko I.A. Phytoclimatic and bioecological characteristics of steppe plantations of various types of light structures. Bulletin of the Dnipropetrovsk University. Biology. Ecology. 2001. Edition 9. P. 221-227.

33. Ivanko I.A. Influence of the type of light structure of forest cultures of biogeocenoses on the length of the root competition of woody and herbaceous species. The issues of steppe forestry and forest land reclamation. 2004. Edition 8. P. 120-129.

34. Ivanko I.A. Development of the doctrine of the types of ecological and light structure of artificial plantations. Ecology and noospherology. 1999. No. 4, Vol. 8. P. 56-63.

35. Ivanov L.A. Solar energy and its use by the plant. Moscow: Scientific word, $1929.47 \mathrm{p}$.

36. Ivanov L.A. Plant physiology. Leningrad: Selkhozgiz, 1931. 243 p.

37. Khromykh N., Lykholat Y., Shupranova L., Kabar A., Didur O., Lykholat T., \& Kulbachko Y. Interspecific differences of antioxidant ability of introduced Chaenomeles species with respect to adaptation to the steppe zone conditions. Biosystems Diversity. 2018. Vol. 26(2).

38. Kholiavchuk D.I. Climatic variability of landscapes of the Ukrainian Carpathians. Physical geography and geomorphology. 2015. Edition 4(80), p. 1. P. 103-107.

39. Kovalski M. Climate - a changing component of forest site. Folia forest pol. A. 1991. No. 3. P. 25-34.

40. Kramarets V.O., Krynytskyi H.T. Assessment of the state and probable threats to the survival of the spruce forests of the Carpathians in connection with climate change. Scientific Bulletin of the National Forestry University of Ukraine. 2009. Edition 19.15. P. 38-50.

41. Lykholat Yu., Alekseeva A., Khromykh N., Ivan'ko I., Kharytonov M., Kovalenko I. Assessment and prediction of viability and metabolic activity of tiliaplatyphyllos in arid steppe climate of Ukraine. Agriculture \& Forestry. 2016. Vol. 62, Issue 3.P. 57-64. 
42. Leslie A. Brandt, Patricia R. Butler, Stephen D. Handler, Maria K. Janowiak, P. Danielle Shannon, Christopher W. Swanston Integrating Science and Management to Assess Forest Ecosystem Vulnerability to Climate Change. Journal of Forestry.Vol. 115, Issue 3, May 2017. P. 212-221.

43. Mirosh O.H. On the issue of the radiation regime under the canopy of artificial honey-locust and white acacia plantations. Issues of steppe forestry and nature protection. 1976. Edition 6. P. 38-45.

44. Mirosh O.H. Materials for the study of the radiation regime of forest biogeocenoses in the Samara River region. Issues of steppe forestry and nature protection. 1975. Edition 5. P. 65-66.

45. Molchanov A.A. Forest and climate. Moscow: Science, 1961. 279 p.

46. Molchanov A.A. Impact of the forest on the environment. Moscow: Science, $1973.358 \mathrm{p}$.

47. Protopopov I.I. Plant temperature and heat balance. Materials of the Main Geophysical Observatory. 1961. Edition 66. P. 41-57.

48. Sakharov M.I. Phytoclimate of forest phytocenoses. Materials of the Bryansk Forestry Institute. Moscow, 1940. Vol. 14. P. 15-38; 52-69.

49. Sedjo Roger A. Climate forests and fire: a North American perspective. Environ. Int. 1998. Vol. 17. No. 2-3. P. 163-168.

50. Tolskyi A.P. The climate of the pine plantations of the Buzuluk pine forest. Meteorological Bulletin. 1918. No. 4. P. 22-26.

51. Tolskyi A.P. Forest and climate. Agricultural meteorology. Moscow: Selkhozgiz, 1938. P. 15-50.

52. Ustsova Z.H. Climate reclamation (on the example of Skrypaievskyi district forestry of the Kharkiv Agricultural Institute). Reclamation role of forest plantations. Kharkiv: Kharkiv Agricultural Institute, 1986. P. 18-29.

53. Vysotskyi H.N. Selected works. Moscow, 1960. 435 p.

54. Vysotskyi H.N. On the hydrological and meteorological impact of forests. Moscow: State Publishing House of Technical and Theoretical Literature, 1938. 68 p.

55. Vysotskyi H.N. The doctrine of the influence of the forest on changes in the environment, its growth and on the surrounding space (Doctrine of forest pertinence). Moscow, 1950. $102 \mathrm{p}$.

56. Vysotskyi H.N. Doctrine of forest pertinence. Leningrad, 1930. $131 \mathrm{p}$.

Надійшла до редколегії 17.09.2021 p. 